\title{
Wrongful Convictions and the State Risk Harm Paradigm
}

\author{
Dr. Myles Frederick McLellan \\ Department of Law and Politics, Algoma University, Canada \\ Correspondence: Dr. Myles Frederick McLellan. E-mail: myles.mclellan@algomau.ca
}

\author{
Received: March 3, 2019 \\ doi:10.11114/ijlpa.v2i1.4117 \\ Accepted: March 25, 2019 \\ Online Published: April 6, 2019 \\ URL: https://doi.org/10.11114/ijlpa.v2i1.4117
}

\begin{abstract}
What has been seen in the last thirty-five years is a significant shift in the psyche of contemporary society. Beck's theory of "risk society" has captured the concerns of governments and its institutions to focus fears on risks and insecurity. Within the criminal justice context, this has led to the pervasive consciousness that crime has become part of the everyday experience to be controlled by risk management techniques framed within Foucault's concept of "governmentality." Crime has become a ubiquitous risk that must be routinely assessed and managed. This shift in criminological thought has also been seen in the move away from the liberal ideals of due process to the favoring of public protection over the rights of individuals found within the normative model of crime control. The problem in this devaluation of due process is the consequent imbalance of power between the individual and the State. Due process rights are enshrined in The Canadian Charter of Rights and Freedoms to protect against this imbalance and are never more important than when loss of liberty is at stake, most particularly when the errors due to the constriction of these rights contribute to the acknowledged systemic factors that lead to wrongful convictions.
\end{abstract}

Keywords: risk, innocence, presumption of innocence, social contract, rights, due process, crime control, fundamental justice, mistaken identification, false confessions, jailhouse informants, wrongful acquittal, state harm, malicious prosecution, negligent investigation, charter damages

\section{Introduction}

It is a fundamental organizing principle of risk reduction and avoidance in western criminal justice systems that the rate of false positives society is prepared to accept is low and the rate of false negatives or acquittals of the guilty is correspondingly high. This principle is often epitomized in what is referred to as Blackstone's ratio "It is better that ten guilty persons escape than that one innocent suffer."1

The risk of error during modern liberalism fell to the State to protect the factually innocent from being wrongly convicted. The 1960's ushered in an era of protection for due process rights that continued for a quarter of a century in the United States and certainly for the first decade following the enactment of The Charter of Rights and Freedoms ${ }^{2}$ in Canada after 1982. Thereafter however, the importance of considerations of the antithetical principles of crime control and public safety in a neoliberal society engendered a shift in the risk of error to fall on the person who is thought to pose a risk of harm. The movement away from the protection of rights to the efficiency of crime control in the criminal justice system as aptly defined by Packer ${ }^{3}$ will be demonstrated. This paper will firstly show how the Supreme Court of Canada ${ }^{4}$ has raised the risk of error for false positives by constitutionally advancing "societal interests" over Charter due process rights that would otherwise guard against the recognized systemic factors that lead to wrongful convictions. ${ }^{5}$

\footnotetext{
1 Blackstone, W. (1765-1769). Commentaries on the Laws of England.

2 The Canadian Charter of Rights and Freedoms, Part I of the Constitution Act, 1982, being Schedule B to the Canada Act 1982 (UK), 1982, c.11

3 Packer, H. (1968). The Limits of the Criminal Sanction. Stanford, Stanford Univ. Press.

${ }^{4}$ Hereinafter referred to as the "Court" unless indicated otherwise
}

${ }^{5}$ These rights include the presumption of innocence, the burden of the prosecution to prove the elements of an offence beyond a reasonable doubt, the prosecution's obligation for disclosure, the right to silence, the right to counsel, protection against unreasonable search and seizure, bail and the right to speedy trial. Most of these rights will be discussed with a view as to how their exercise has an effect on the 


\section{Risk Theories}

\subsection{Governmentality}

Michel Foucault introduced the term governmentality in the 1970s as a function of his writings on political power. ${ }^{6}$ Foucault argued that a certain way of thinking that he called governmentality had become the common ground of all modern forms of political thought and action. In part Foucault was making sense of the transformations in the art of governance that was underway in the western world. These transformations took the form of substantial criticism to the welfare state, universal insurance, and virtually all aspects of the social state that had taken place in the first three quarters of the twentieth century. Modern liberalism was replaced by neoliberalism which created a revised rationality for government in the name of freedom and utilized a range of techniques that enabled the state to divest itself of many of its obligations by responsibilizing non-state entities.

In 1991 papers were written by Francois Ewald and Robert Castel that examined risk within the context of this analytic framework. ${ }^{7}$ These "landmark papers in the development of governmental approaches to risk... are worth special attention" 8 Risk for governmentality is a political rationality that provides a framework for envisaging and dealing with problems. The distinguishing characteristic of risk is that it is a particular way in which problems can be viewed or imagined. What is specific to risk is that large numbers of events can be sorted into a distribution and that distribution in turn can be used as a means of making probabilistic predictions. According to Pat O'Malley, for governmentality "attention therefore is paid to the ways in which the increasingly prevalent adoption of risk as a framework of government creates new subjectivities and redefined relationships" Simply put "to govern something as a risk is to identify a future condition as being more or less probable, and to set in train ways of responding that will affect this probability in some way." 10

For Ewald insurance was seen as a method that could spread risks over a population for future specified but uncertain harms. Insurance is not interested in creating detailed case records of every insured party or object; rather it focuses on relevant "risk factors" that act as predictors of insured events. In this way "risk pools" are created wherein a group of identified interests have a similar probability of experiencing some uncertain condition in the future for which insurance will deal with in an agreed upon way. Castel on the other hand outlined the engagement of risk technologies in relation to the practice of psychiatry. While Ewald and his reflections on insurance dealt with spreading of risks, the fundamental feature for Castel psychiatric model was risk reduction. Indeed Castel identified risk reduction as the central theme of the new preventative policies. ${ }^{11}$ The rise of risk as a way of thinking transformed decision making for mental health issues and gave way for actuarial management over clinical intervention. As with insurance, the presence of a risk factor for the purposes of a psychiatric diagnosis consigned prospective patients to a risk pool. In this way suggested preventative strategies working on whole categories of people removed the notion of the subject or concrete individual and put in its place a combination of factors of risk for the purposes of such diagnosis.

\subsection{Risk Society}

At the same time as the release of this governmentality literature in the early 1990s, Ulrich Beck provided an alternate strategy on the importance of risk in relation to governance which he called "risk society". ${ }^{12}$ For Beck it was "uncertainty" as the primary non-probabilistic way in which government based expectations on how the future was likely to unfold that was central. While Beck recognized that risks involved statistical predictions of the future, "uncertainty" consisted rather of other organized forms of prediction which included professional judgment and rules of thumb. He saw that "modernization risks"

factors leading to wrongful convictions, including their implications for tainted eyewitness identification, problematic police interrogation procedures, false confessions, and perjured jailhouse informant testimony. The right against unreasonable search and seizure, the right to bail and the right to be tried within a reasonable time will not be dealt with in this paper as these rights are not endemic to wrongful convictions.

6 Foucault, Michael. "Governmentality" in in Burchell, G., Gordon, C., \& Miller, P. (eds.). (1991). The Foucault Effect: Studies in Governmentality. Chicago, The Univ. of Chicago Press at pp.87-104.

7 Ewald, F. Insurance and Risk (Chp.10)., \& Castel, R., From Dangerousness to Risk (Chp.14) in Burchell, G., Gordon, C., \& Miller, P. (eds.) (1991). The Foucault Effect: Studies in Governmentality. Chicago, The Univ. of Chicago Press.

8 O'Malley, Pat. (2008). Governmentality and Risk: Social Theories of Risk and Uncertainty, Zinn, J. (ed.). Oxford, Sydney Law School Research Paper at p.4.

9 Ibid at p.10.

10 Ibid at p.3.

11 Castel, supra at note 7, pp. 281,288.

12 Beck, U. (1992). Risk Society: Toward a New Modernity. London, SAGE Publishers. 
such as global warming, ozone layer depletion and nuclear accident were threats to human existence and could not be the subject of statistical analysis. These were "one-off" events. However, O'Malley argues that "uncertainty" should not be regarded simply as the "incalculable" alternate to risk, but as a distinct way of governing that includes the broader category of "foresight". This also does not mean that with the ubiquitous focus on the government of risks that one should necessarily assume that risks have become greater than was once the case. What has changed is the "increased propensity to govern in terms of risk"13 The difference in approach between the governmentalists and the risk society theorists is that the former see risk as a probabilistic prediction based on the distribution of events and the latter center upon uncertainty as an estimation of future harm based upon judgment.

\subsection{Risk Based Governance}

For the purposes of this paper and the implications of risk theory as applied to criminal justice it is probabilistic risk based governance that is of primary importance as a means of risk reduction, particularly in light of the observation that since the 1970's "no risk has preoccupied Americans more than that of crime." 14 This was a function of what David Garland saw as three social developments in the last quarter of the twentieth century that formed the basis of a change in sociological and criminological discourse as a result of an emerging culture of control. ${ }^{15}$

It was in the light of changing middle-class attitudes to crime and control that this transformation took place. The first change took hold as a function of the organizational adjustments to middle class lifestyles. The transportation of children to school and child care, long commutes to work, and significant disassociate realities to the familial environment all led to "the new element of precariousness and insecurity...into the fabric of everyday life."16 Garland rationalized this to the creation of an enhanced need in society to establish control over risks and uncertainties. This, in turn, resulted in a need to know about the exposure of risks from the criminal justice system and heightened awareness of "dangerous" others.

The second development was the defining of deviance down resulting from the lessening ability of the sovereign state in crime control. The relaxation of law enforcement at the lower end of the crime pool produced increasing public anxiety about the security being provided for all those perceived criminal activities pervasive in modern society. In turn, the third change further exacerbated the "crime consciousness" with the impact of mass media and the popular depictions of crime that led the audience to fear crime as an everyday event that potentially victimized an exaggerated number of individuals on a regular basis. Garland summed up these historical circumstances emphasizing high crime rates and increased insecurity in the institutional form of the "crime complex"17 In this regard, he examined the changes to the criminal justice systems in the two "late-modern" societies of the United Kingdom and the United States at the macro-level to view the structural patterns and to identify the changes in criminological theory and crime prevention.

In the last thirty years in Canada and other western liberal democracies, there has been a growing concern that:

... "justice" is very much under threat in the "risk society". In contemporary western societies adherence to long held principles of justice is endangered by excessive concern with safety: fear of crime and fear of terrorism are rational fears, but are heightened to the point where they overwhelm our care for liberty and justice. ${ }^{18}$

In this regard, the widespread application of risk theories as they have evolved over the past three decades has dominated the way governments, private enterprise and individuals organize their everyday activities. ${ }^{19}$

13 O'Malley, supra at note 8, p.5.

14 Simon, J. (2005). Risk and Reflexivity: What Socio-Legal Studies Add to the Study of Risk, Meador Lecture Series 2004-2005: Risk and the Law. Alabama. L. Rev. 57 (1) 119 - 140 at p.129.

15 Garland, D. (2001). The Culture of Control: Crime and Social Order in Contemporary Society. Chicago, The University of Chicago Press.

16 Ibid at p. 155.

17 Ibid at p. 163.

18 Hudson, B. (2003). Justice in the Risk Society: Challenging and Re-Affirming Justice in Late Modernity. London, Sage Publications at p. $\mathrm{x}$ (Introduction).

19 In 1985, Stan Cohen wrote that the individual had ceased to be the concern of an emerging generation of criminology, criminal justice and social control and said "... what is being monitored is behavior... No one is interested in inner thoughts...the game is up for all policies directed to the criminal as an individual, either in terms of detecting (blaming and punishing) or causation (finding motivational or causal chains)..The technological paraphernalia directed at the individual will now be invested in cybernetics, management, systems analysis, surveillance, information gathering and opportunity reduction. This might turn out to be the most radical form of behaviourism imaginable - prevention of the act of crime by the direct control of whole populations, categories and spaces." Cohen, S. (1985) Visions of Social Control: Crime, Punishment and Classification Cambridge, Polity Press at pp. 146-147. In 2001, David Garland stated that "This desire for 
Before this dramatic shift in criminological discourse, for more than a century there was a penal welfarism that was underscored with the liberal ideals of "due process and proportionate punishment with a correctionist commitment to rehabilitation, welfare and criminological expertise". ${ }^{20}$ As part of the progressive movement in the 1960's to address discrimination, calls were made to protect minority rights by enhancing prisoner's rights, restrict state power and promote decarceration. With respect to punishment, this movement supported replacing indeterminate sentencing with more fixed and certain penalties within the framework of sentencing guidelines. What ending up happening over the course of the next two decades however was the opposite. What occurred was the unforeseen utility of greater incarceration primarily as a function of a litany of offences that attracted mandatory minimum sentences and pervasive hard line policies of deterrence.

Starting in the 1970's, crime came to be seen not as a problem centred upon individual deviance needing correction through rehabilitation, but rather a matter that required severe controls, disincentives and segregation of offenders. To a great degree this shift was the realization that "the threat of crime has become a routine part of modern consciousness, a standing possibility that is constantly to be 'kept in mind'. Crime has become an everyday risk that must be routinely assessed and managed." 21

This changing outlook on crime control and prevention was heralded with the recognition that governments as sovereign states were incapable of being the sole providers of law and order. In turn, this engendered a focus on the effects of crime rather than the causes. Garland described the two strategies that developed in this environment as firstly the creation of the preventative partnership between the government and the private sector, and secondly punitive segregation. The latter approach endorsed the turn to harsher sentences and the increasing use of imprisonment. At the same time, the engagement of professional expertise diminished significantly in the arena of policy making in the face of highly politicized decision making.

All of these transitions as described by Garland were the result of what he termed the "increased salience of crime" 22 This shift away from the rehabilitative approach to the welfare state resulted into what was termed "actuarial justice". ${ }^{23}$ Whereas the primary concern of "penal modernism" was directed to the rehabilitation of individual offenders, the "new penology" adopted a risk model of governance based upon probabilities and statistical distributions. This was not unlike Castel's position relative to changes in the treatment of mental illness where risk factors and actuarial management of risk populations replaced clinical assessment. Indeed:

...the new penology is markedly less concerned with responsibility, fault, moral sensibility, diagnosis, or intervention and treatment of the individual offender. Rather, it is concerned with techniques to identify, classify, and manage groupings sorted by dangerousness. The task is managerial, not transformative. It seeks to regulate levels of deviance, not intervene or respond to individual deviants or social malformations. ${ }^{24}$

As such, the new penology's goal was not to eliminate crime but to make it tolerable through systemic coordination. The emerging risk techniques in crime control tended to use statistical methods to correlate pre-existing conditions and criminal actions and to treat these conditions as "risk factors". These factors were used to identify individuals as part of a category of potential offenders and thereby assign them to a certain "risk pool". ${ }^{25}$ It was "risk categorization" rather than the uniqueness of individuals that became of interest.

\subsection{Risk and the Law}

For the purpose of risk reduction, the law is a risk technique which is used to shape the conduct of individuals in relation to things identified as risks. With particular regard to what has become a safety-dominated forward looking approach, the law may restrict the rights and liberties of individuals not because of what they have done in the past but solely to protect society against a perceived risk of causing harm in the future. In this way, law can be used to manage, control and sometimes

security, orderliness, and control, for the management of risk and the taming of chance is, to be sure, an underlying theme in any culture. But in Britain and America in recent decades that theme has become a more dominate one, with immediate consequences for those caught up in its repressive demands, and more diffuse, corrosive effects for the rest of us." Garland, supra at note 15, p.194.

${ }^{20}$ Ibid at p.27.

21 Ibid at p. 105.

22 Ibid at p. 152.

23 Feeley, M. \& Simon, J. (1992). The new penology: Notes on the emerging strategy of corrections and its implications. Criminology, 30, 449-474; and Feeley, M. \& Simon, J. (1994). Actuarial justice: The emerging new criminal law. In D. Nelken (eds.) The Futures of Criminology London: Sage Publications.

24 Ibid at p.452.

25 O’Malley, P. (2010). Crime and Risk. London, Sage Publishing at p.2. 
incapacitate members of groups that are seen to pose a risk.

It is hard to deny that there are some circumstances in which the State has the right to restrict liberty in order to protect the public. However, this inevitably leads to considerations of just who should belong to the "risk pool" where liberty is to be curtailed as a probalistic prediction rather than a materialization of harm. This raises the problem of over-inclusiveness and the prospect of false positives in the criminal justice process resulting in wrongful convictions.

\subsection{Risk and Rights}

Potential offenders have become a risk to the public which "inevitably permeate[s] through the courts into thinking about rights." ${ }^{26}$ Liz Campbell relying upon Garland contextualizes these propositions by seeing that "throughout the pre-trial stage of the criminal process, the court-hearing and sentencing, a shift in focus from the due process rights of the accused towards the result-oriented aims of the State is apparent." ${ }^{27}$ Barbara Hudson, as well, believes that justice has become now very much less important than risk as a preoccupation of criminal justice conceptualized by neo-liberalism. ${ }^{28}$ The law and order agenda of western governments has emboldened a significant shift from doing justice to managing risk as its goal. This leads one inexorably to consider to whom are rights owed and under what circumstances can they be derogated.

The rights and freedoms enshrined in the Charter that are most often engaged in the criminal justice process are the fundamental freedoms found in s.2; legal rights in ss.7 to 14; and equality rights as set out in s.15. It has been suggested that such rights and freedoms exist in a hierarchy that are differentiated according to the permissibility of their derogation. ${ }^{29}$ At the top of the hierarchy are rights which are non-derogable, rights which must be upheld in all circumstances and must never be suspended for public interest reasons. These are the "right to life; the right not to be subjected to torture or to inhuman or degrading treatment; the right not to be subjected to forced labour, and the right not to be subjected to retrospective criminal law or penalties." ${ }^{.30}$ These protections are most broadly contained in Canada under s.7 of the Charter. The second level of rights is often referred to as the fair trial rights which most importantly contain the rights to due process. In the Charter, these rights are most particularly found in ss.7 to $14 .^{31}$ These rights are not absolute and may be rescinded on occasion, but it is argued that they should be limited only under the most pressing circumstances and that their suspension requires very powerful justification $^{32}$. Third-level rights may be suspended or curtailed when necessary for national security, or when they interfere with the rights of other persons or groups. These third level rights include the right to freedom of expression, the right to freedom of thought and religion, the right to freedom of assembly and association, and the right to respect for private life. In Canada, these rights are referred to as fundamental freedoms as found under s. 2 of the Charter. These third-tier rights are best regarded by some scholars as civil rights rather than human rights ${ }^{33}$. This is the case because these rights or freedoms can vary over time with a change in the cultural context.

Hudson believes that the evolving systems of risk control "violate some of the fundamental tenets of due process" 34 and by doing so appear to allow derogation of second tier rights. As such, the risk pool of the accused is subject to the exposure of a higher risk of harm due to a diminishment of rights that are intended to provide constitutional constraints on the investigative and prosecutorial powers of the State.

26 Ibid at p.467.

27 Campbell, L. (2006). Decline of Due Process in the Irish Justice System: Beyond the Culture of Control. Hibernian Law Journal, 6, 125 -158 at p. 126.

${ }^{28}$ Hudson, B. Punishment, Rights and Difference: Defending Justice in The Risk Society. Chapter 8, at p.144 in Stenson. K., \& Sullivan. R. (eds.). (2012). Risk, Crime and Prudentialism Revisited. Crime, Risk and Justice: The Politics of Crime Control in Liberal Democracies. London, Willan.

29 See: Emmerson, B., Ashworth, A., \& Macdonald, A. (eds.). (2007). Human Rights and Criminal Justice (2nd). London, Sweet \& Maxwell.

${ }^{30}$ Hudson, supra at note18, p.69.

31 More particularly, these rights include the right to be secure against unreasonable search and seizure; the right not to be arbitrarily detained or imprisoned; the right upon arrest or detention to be informed of the reasons therefor and to retain counsel without delay; the right to be informed of the predicate offence without delay; to be tried in a reasonable time; to be presumed innocent until proven guilty; not to be denied reasonable bail; the right against double jeopardy and the right not to give self-incriminating evidence.

${ }^{32}$ Hudson, supra at note 28 p.27.

33 Ibid at p.69.

34 Ibid. 


\section{Rights and the Systemic Causes of Wrongful Conviction}

\subsection{The Charter and Due Process}

\section{"In the end, a good lawyer is the best defense against wrongful convictions ${ }^{135}$}

At no time in the criminal justice process is the risk of error more acute than at the investigatory stage of a case, both pre- and post-charge where the police are gathering evidence in their pursuit to establish both the existence of criminality and their case against the accused. An error made by the police which points their investigation to an accused who is in fact, innocent, is not easily undone and may well lead to a wrongful conviction. Due process rights and the rules of evidence are existing safeguards for all accused individuals.

The Charter's legal rights provisions in sections 7 through 14 impose constitutional restraints on the investigative powers of police, protections that are supplemented by guarantees that are directed at ensuring fair treatment for individuals once they are detained or charged with a crime. These guarantees, combined with the remedial provision of section 24(1) and the discretion to exclude unconstitutionally-obtained evidence under section 24(2) exist to strike a proper balance between the interests of the individual and societal interests as determined by State decisions to restrict those rights. It is the job of defence counsel to energetically and vigorously defend the constitutional rights of her client so that the existence of factual innocence translates to a dismissal or withdrawal of proceedings before trial, or a finding of not guilty at trial.

The Charter's promotion of due process started out in earnest with three early judgments by the Court ${ }^{36}$ giving clear recognition that the Charter's role is to control legislative abridgments of rights. The Court held that if the police undertook an activity that allegedly breached a right that afforded an accused protection under the Charter, it was the court's role to uphold that right against the actions of the state. Nevertheless, and over time the Court has narrowed the opportunity for defence counsel to successfully argue that evidence gathered by the police should be excluded at trial on the basis that the defendant's rights have been infringed. Firstly the analysis of the Court's scrutiny of constitutional rights as it was conducted within the parameters of section 1 will be discussed, followed by a review as to how the Court has moved that review from section 1 to an examination of an alleged breach of rights as found in a specific section. ${ }^{37}$ This is particularly important for the protection of Charter rights in the face of police activity that has not been authorized by either statute or the common law. Such activity is particularly relevant when the right to counsel, the right to remain silent and how confessions are admitted into evidence are at play, together with otherwise tainted evidence such as mistaken eyewitness identifications and jailhouse informant testimony. Lastly it will be seen that the Court has dramatically restricted the exclusion of evidence, even when it is constitutionally tainted because there now exists a presumption of good faith on the part of police conduct.

As a precursor to reviewing the protections to an accused as provided by the due process provisions of the Charter, it is important to state that underscoring these rights is the presumption of innocence. The presumption of innocence has a significant historical pedigree and is the backbone of the common law approach to administering the criminal law. The House of Lords' timeless statement in Woolmington v D.P.P. ${ }^{38}$ remains relevant today:

Throughout the web of the English Criminal Law one golden thread is always to be seen, that is the duty of the prosecution to prove the prisoner's guilt [...] and no attempt to whittle it down can be entertained. ${ }^{39}$

The point of the presumption of innocence is a liberal one: the state must justify any interference with the freedom of the individual and be put to the strict proof of any allegations against her. The presumption of innocence is constitutionally protected under the Charter s.11 (d). This provision provides procedural and evidentiary protection to an accused once a charge has been laid.

An integral part of the presumption of innocence is the reasonable doubt standard of proof. Justice Cory in R. $v$ Lifchus ${ }^{40}$

35 Reno, J. Remarks at the American 2000 National Symposium of Indigent Defence, as noted in Worden, A.P.S., Lucas, A., \& Blaize Brown. E. (2010). Patchwork of Policies: Justice, Due Process, and Public Defense across American States. Alb. L. Rev. $74: 1423$ - 1464 at p.1423.

36 R. v Big M Drug Mart [1985] 1 SCR 295; Hunter et al v Southam Inc. [1984] 2 SCR 145; Andrews v Law Society of British Columbia [1989] 1 SCR 143.

37 The evolution on this approach to challenging the abridgment of Charter rights is described as the Court's movement from utilizing "external" limits on rights to "internal" limits on rights. See Roach, K. (2007). Unreliable Evidence and Wrongful Convictions: The Case for Excluding Tainted Identification Evidence and Jailhouse and Coerced Confessions. C Crim. L. Q., $210-236$.

38 [1935] A.C. 462.

39 Ibid at pa.7.

40 [1997] 3 SCR 320. 
succinctly situates this burden within the presumption and within the context of wrongful convictions:

The onus resting upon the Crown to prove the guilt of the accused beyond a reasonable doubt is inextricably linked to the presumption of innocence. That jurors clearly understand the meaning of the term is of fundamental importance to our criminal justice system. It is one of the principal safeguards which seek to ensure that no innocent person is convicted. The Marshall, Morin and Milgaard cases serve as a constant reminder that our system, with all its protections for the accused, can still make tragic errors. A fair trial must be the goal of criminal justice. There cannot be a fair trial if jurors do not clearly understand the basic and fundamentally important concept of the standard of proof that the Crown must meet in order to obtain a conviction. ${ }^{41}$

Charter analysis on the extent a right protects an accused against State activity, including actions by the police and by Crown attorneys, has followed a relatively standard form since the Court's ruling in $R$. v Oakes ${ }^{42}$ a fundamental decision that outlines when and how rights can be overridden in certain, limited circumstances.

\subsection{Section 1- The Oakes Test}

In the course of a criminal trial, when defence counsel believes that evidence to be tendered by the Crown has been obtained by virtue of a Charter breach, a motion will be made under s.24(2) of the Charter to exclude that evidence before its admission. ${ }^{43}$

At the first stage of the analysis, a court determines the scope of the substantive Charter guarantee and determines whether an infringement has been made out. If a Charter breach is established, the court then moves on to consider whether the infringement can be "saved" under section 1 . Section 1 states:

The Canadian Charter of Rights and Freedoms guarantees the rights and freedoms set out in it subject only to such reasonable limits prescribed by law as can be demonstrably justified in a free and democratic society

The court begins by asking whether the Charter violation is "prescribed by law". ${ }^{44}$ This stage of the analysis requires the state to show that the infringement is legally authorized, by either statute or by the common law.

If the limit is "prescribed by law", the court moves on to consider whether the legislation or government action furthers a pressing and substantial objective, whether it is minimally impairing, and whether it is proportional, in that its benefits exceed its costs. Since the government's objective is often to further "society's interest" in some way, interest balancing occurs as a matter of course under section 1. In other words, if government action that infringes Charter rights is to be upheld under this section, the benefits to society must exceed the costs to an individual's rights.

However, in some cases police take action that has no basis in statute or common law, in such cases, police may be acting "outside the law". In this regard, police might obtain evidence that is not authorized by virtue of a statute such as the Code, or otherwise requires a warrant before its collection, for example. If there is no such basis and there is an infringement of a Charter right, then the action is not "prescribed by law" and therefore cannot be "saved" by s.1. The analysis then proceeds directly to the question of whether the evidence should be excluded under section 24(2) of the Charter. The "prescribed by law" requirement therefore limits the function of the court. It is interesting to note that internationally "Proportionality analysis - the Oakes test to Canadians - is the dominant approach globally for adjudicating human rights claims today." 45

\subsection{A Principle of Fundamental Justice}

The Court has also looked to s.7 in recognition of the risk of wrongful conviction. The section reads:

Everyone has the right to life, liberty and security of the person and the right not to be deprived thereof except in accordance with the principles of fundamental justice

\footnotetext{
41 Ibid at pa.13.

42 [1986] 1 SCR 103.

${ }^{43}$ In the event that the trier of fact is a jury, the motion will be by way of a voir dire to be heard in the absence of the jury, so that the jury does not know what the nature of the impugned evidence might be. The phrase "voir dire" is not used in the Code, per se. The provision that deals with this process is found in s.645 of the Code. The test is whether the admission of the evidence will bring the "administration of justice into disrepute" as set out in the wording of s.24 (2).

44 Oakes, supra at note 42, p.135.

45 Mathews, J. (2018). Rights in the Balance. Review of Constitutional Studies, 23 (1), 225 - 233 at p.225.
} 
In United States of America v. Burns, ${ }^{46}$ the Court took notice of the reality of wrongful convictions and reinforced the principle that the innocent not be punished as one of the unifying principles of section 7 as it relates to the administration of justice. The principle that the innocent not be punished stands for an accepted commitment that our justice system will take all reasonable precautions to prevent wrongful convictions. The Court stated:

Legal systems have to live with the possibility of error. The unique feature of capital punishment is that it puts beyond recall the possibility of correction. In recent years, aided by advances in the forensic sciences, including DNA testing, the courts and governments in this country and elsewhere have come to acknowledge a number of instances of wrongful convictions for murder despite all of the careful safeguards put in place for the protection of the innocent. The instances in Canada are few, but if capital punishment had been carried out, the result could have been the killing by the government of innocent individuals. The names of Marshall, Milgaard, Morin, Sophonow and Parsons signal prudence and caution in a murder case... ${ }^{47}$

Courts have established that a number of rights exist under section 7, including the right to silence and the confessions rule, the right to counsel ${ }^{48}$ the right to a full answer and defence which includes Crown disclosure, as well as the general right to exclude otherwise tainted evidence due to its propensity to cause wrongful convictions. It is interesting to note however that case law has illustrated that it is by reference to section 7 where courts have engaged in the balancing of rights and "societal interests" rather than through the traditional exercise undertaken by virtue of applying the s.1 analysis in Oakes to Charter infringements.

In $R . v$ Sinclair ${ }^{49}$ the Court's seminal decision on the right to counsel, the majority set out that:

....in defining the contours of the s. 7 right to silence and related Charter rights, consideration must be given not only to the protection of the rights of the accused but also to the societal interest in the investigation and solving of crimes $^{50}$

This approach to Charter interpretation gives constitutional weight to considerations of societal interests when delineating the scope of the legal rights of the accused, rather than at the later stage of determining whether a violation of those rights is justified under s.1. The Court made it clear that an accused does not have the right to counsel present while being interrogated by the police but does have the right to remain silent. The difference is pointed out by way of noting:

I do not believe that many clients detained by the police and placed in an interview room appreciate the subtle difference between the fact that they have a right to refuse to talk to the police unless a lawyer is present and the fact that they have no right to have a lawyer present while being interrogated by the police. ${ }^{51}$

Kent Roach proposes that section 7 provides a right to the exclusion of unreliable evidence by virtue of the principle laid down in Burns ${ }^{52}$ that the innocent should not be punished and the courts should be proactive in avoiding wrongful convictions. ${ }^{53}$ As such section 7 is significant in its utility as a right to address the systemic factors that lead to wrongful convictions, including, inter alia, mistaken eyewitness identification, false confessions and perjured testimony from jailhouse informants. ${ }^{54}$

\subsection{Mistaken Eyewitness Identification}

Eyewitness identification is a critical tool for investigating and prosecuting criminals. This type of evidence is among the most persuasive testimony that can be used in a courtroom. A positive identification of an accused in court is an

46 [2001] 1 SCR 283. In this case two Canadian citizens were under threat of extradition to the United States, where they would face the death penalty if found guilty of the crimes of which they were accused. The Canadian government did not want to extradite them to the United States without assurances that the death penalty would not be sought.

47 Ibid at pa.1. While this case dealt with an application to extradite the accused to the United States on a charge of first degree murder where the death penalty was available, the sentiment of the Court to the prospect of wrongful convictions is emphasized.

48 As distinguished from the right under s.10 (b) to retain and instruct counsel.

49 [2010] 2 SCR 310.

50 Ibid at pa.63.

51 Orris, G. (2017). Section 10(b) of the Canadian Charter of Rights and Freedoms: Legal Advice. The Advocate, 355 at p.361.

52 Burns, supra at note 46.

53 Roach, supra at note 37.

54 The other sections of the Charter, such as s.8: right against unreasonable search and seizure; section 9: right against arbitrary detention; s.10(b) right to counsel; s.10(c) right of habeas corpus; s.11(b) right against undue delay; s.11(e) right to bail may well in individual cases play a contributing part in a wrongful conviction. However, the infringement of these rights is not necessarily systemic to wrongful convictions and as such, will not be examined at length in this paper. 
essential element for any successful prosecution. It is powerful and compelling evidence often given by a confident and positive witness... However, we know that mistakes have happened. Well-meaning, honest and credible people can and have been wrong... ${ }^{55}$

Mistaken eyewitness identifications have been identified as the leading cause of wrongful convictions. ${ }^{56}$ The Innocence Project states that research shows that the human mind is not like a tape recorder. People do not record events exactly as they see them, nor recall them like a tape that has been rewound. Eye witness memory "must be preserved carefully and retrieved methodically, or it can be contaminated". 57

False identifications are exceptionally difficult for defence counsel to refute in cross-examination because mistaken witnesses often believe they are telling the truth. Defence counsel in many American courts rely on expert testimony to discredit questionable eyewitness testimony, as experts can bolster their testimony by referring to the large body of psychological research in this area. Unfortunately, there is authority that restricts the admissibility of expert evidence on the frailties of eyewitness identification in Canadian courts. In $R . v$ MacIntosh and McCarthy $y^{58}$ counsel for the defence proposed to adduce evidence from a psychologist as to the inherent frailty of such evidence. The trial judge refused to accept this evidence as an expert opinion. Justice Finlayson of the Court of Appeal for Ontario made it very clear that evidence from the behavioural sciences was to be treated quite differently than that from the natural sciences. He unequivocally held that this type of evidence was not outside the experience of triers of fact.

In $R . v$ Henderson,$^{59}$ the Manitoba Court of Appeal dealt with a trial record that contained both a caution by the judge and an expert opinion as to the frailty of eyewitness identification. The appeal court restated its earlier decision that cautioned trial judges against letting expert witnesses appropriate the function and role of the trier of fact. The court made clear that "while the concerns over the frailties of eyewitness identification are real, they are generally best addressed through strong jury instructions as opposed to thorough expert testimony" 60 At the end of the day and having regard to the fact that the witness personally knew the accused, the eyewitness testimony was allowed to stand on the appeal.

The strength of the judge's caution to a jury regarding the reliability of eyewitness testimony was also at issue in the Court's earlier decision in R. v Hibbert ${ }^{61}$ where a real estate agent was a victim of a brutal attack while she was holding an open house. When the victim took her assailant to look at the garage, she was struck from behind, beaten and strangled her until she was unconscious. The Crown's case against the accused was based largely on circumstantial evidence and fundamentally rested upon the victim making an in-court identification of the accused.

The accused was convicted, and on appeal argued the inherent weakness of eyewitness identification evidence and in particular the need for forceful instructions by the trial judge to the jury emphasizing such weakness. The Court held that the judge's directions to the jury on identification evidence were not so deficient as to constitute an error of law. However, the Court held that the trial judge should have cautioned the jury more strongly that the identification of the accused in court was highly problematic as direct reliable identification of the perpetrator of the offence. Justice Arbour for the majority of the Court stated:

It is important to remember that the danger associated with eyewitness in-court identification is that it is deceptively credible, largely because it is honest and sincere. The dramatic impact of the identification taking place in court, before the jury, can aggravate the distorted value that the jury may place on it. The instruction to the effect that such identification should be accorded "little weight" does not go far enough to displace the danger that the jury could still give it weight that it does not deserve. ${ }^{62}$

Justice Arbour also said:

The danger of wrongful conviction arising from faulty but apparently persuasive eyewitness identification has been well documented. Most recently the Honourable Peter deC. Cory, acting as Commissioner in the Inquiry regarding

55 Federal Provincial Territorial Heads of Prosecutions Committee. (2011). The Path to Justice: Preventing Wrongful Convictions at p.55.

56 MacFarlane, B. (2006). Convicting the Innocent: A Triple Failure of Justice. Man. L. J. 31, $403-488$.

57 Innocence Project, Affiliated with the Benjamin N. Cardozo School of Law at Yeshiva University, New York.

58 (1997) 35 OR (3d) 97.

592012 MBCA 93.

${ }^{60} \mathrm{Ibid}$ at pa. 109. This decision relied upon the Court's decision in R. v. D.D. [2000] 2 S.C.R. 275 that stated "[t]he primary danger arising from the admission of any opinion evidence is that the province of the jury might be usurped by that of the witness" at pa.53.

61 [2002] 2 SCR 445.

62 Ibid at pa.50. 
Thomas Sophonow, made recommendations regarding the conduct of live and photo line-ups, and called for stronger warnings to the jury than were issued in the present case (Peter de C. Cory, The Inquiry Regarding Thomas Sophonow: The Investigation, Prosecution and Consideration of Entitlement to Compensation (2001) ("Sophonow Inquiry"), at pp. 31-34). ${ }^{63}$

The Court overturned the conviction and ordered a new trial. ${ }^{64}$

\subsection{False Confessions}

As counterintuitive as it may seem, factually innocent people confess to crimes they have not committed. Within the context of wrongful convictions, these confessions are more often than not the result of an abusive police interrogation. The Innocence Project ${ }^{65}$ has indicated that a variety of factors can contribute to a false confession during a police interrogation. Many cases have included a combination of several of these causes, including "duress, coercion, intoxication, diminished capacity, mental impairment, ignorance of the law, fear of violence, the actual infliction of harm, the threat of a harsh sentence and the misunderstanding the situation"66

The Court has as well identified the danger of this systemic factor leading to wrongful convictions. In R. v. Oickle ${ }^{67}$ the Court recognized:

A large body of literature has developed documenting hundreds of cases where confessions have been proven false by DNA evidence, subsequent confessions by the true perpetrator, and other such independent sources of evidence... One of the overriding concerns of the criminal justice system is that the innocent must not be convicted: see, e.g., R. v. Mills, [1999] 3 S.C.R. 668, at para. 71; R. v. Leipert, [1997] 1 S.C.R. 281, at para. 4. Given the important role of false confessions in convicting the innocent, the confessions rule must understand why false confessions occur. ${ }^{68}$

In this case, the Court established the confessions rule - which ascertains that confessions can only be admitted if they are voluntary and not the result of coercive police tactics, which included threats or promises ${ }^{69}$ oppression, ${ }^{70}$ and other police trickery ${ }^{71}$ and must be obtained from individuals who show evidence of an "operating mind". ${ }^{72}$ The Court however went onto to say that "false confessions are rarely the product of proper police techniques." 73 Christopher Sherrin takes issue with this conclusion and urges greater consideration of risk factors that make some accused susceptible to false confessions "including sleep deprivation, intoxication and withdrawal from drugs, intellectual disabilities and youth." 74

The Court in defining the confessions rule kept in mind the twin goals of protecting the rights of the accused without unduly limiting society's need to investigate and solve crimes. The confessions rule deals most particularly with false confessions and the dangers of improper interrogation techniques. Within the context of a police interrogation, where the detainee knows she is speaking to a person in authority, the finding that the confession was voluntary is "determinative of the s. 7 issue. ${ }^{75}$ Further the Court made clear:

The common law confessions rule is well-suited to protect against false confessions. While its overriding concern is with voluntariness, this concept overlaps with reliability. A confession that is not voluntary will often (though not

63 Ibid at pa.49.

${ }^{64}$ For a discussion on the inaccuracy of eyewitness testimony and possible reforms see: See Thompson, S. (2008). Beyond a Reasonable Doubt - Reconsidering Uncorroborated Eyewitness Identification Testimony. U.C. Davis L. Rev. 41(4), 1487 - 1546 \& Roach, K. (2010). Wrongful Convictions: Adversarial and Inquisitorial Themes. N.C. Int'l. \& Com. Reg., 35 (2). 387 - 446.

65 Supra at note 57.

66 Ibid.

${ }^{67}$ [2000] 2 SCR 3.

68 Ibid at pa.35-36.

69 Ibid at pa.48-57.

70 Ibid at pa.58-62.

71 Ibid at pa.65-67.

72 Ibid at pa.63-64.

73 Ibid at pa.45.

74 Roach, K. (2012). Wrongful Convictions in Canada. U. of Cinn. L.R. 80 (4), 1465 - 1526 referencing Sherrin, C. (2005). False Confessions and Admissions in Canadian Law. Queens L. J. 30 (2), $601-659$ at p.650.

75 Oickle, supra at note 67, pa.33. 
always) be unreliable. ${ }^{76}$

The confessions rule is also applicable to the accused's common law right to remain silent which can be contrasted with a s.7 right to remain silent. The question turns on whether inculpatory evidence, including prospectively false confessions should be allowed into the record when police act concertedly to circumvent an accused's right to remain silent to persons in authority. If the accused chooses voluntarily to make incriminating admissions, should the law nevertheless sanction the police behaviour by excluding the evidence?

This was the question before the Court in R. v. Singh. ${ }^{77}$ Jagrup Singh, a 28-year-old truck driver, was detained and questioned by the police after a fatal shooting outside a strip club in Surrey, B.C. During the interrogation Singh asserted his right to remain silent eighteen times. The police nevertheless persisted in what the trial judge described as an "effort to get him to confess, no matter what". ${ }^{78}$ Eventually, Singh made an incriminating admission that resulted in his conviction. On appeal, Singh conceded that his admission had been "voluntary" for the purposes of the common law confessions rule, but that the persistent interrogation had nevertheless violated his s. 7 Charter right to silence. Thus, the question before the Court was whether the Charter provided residual protection to an accused in such circumstances, even where the common law would have allowed the admission into evidence. The Court ruled that, in the context of a detained person knowingly speaking to authorities, the confessions rule and right to silence are "functionally equivalent" - both turn on whether the confession meets a "voluntariness" test.

Nevertheless, s. 7 enshrines, as a principle of fundamental justice, a stand-alone right to silence. Chief Justice McLachlin in $R v$. Hebert $^{79}$ saw the $\mathrm{s} .7$ right to silence as providing protection where the confessions rule could not since, as she explained:

[T] his suggests that the drafters of the Charter viewed the ambit of the right to silence embodied in $\mathrm{s.} 7$ as extending beyond the narrow formulation of the confessions rule, comprehending not only the negative right to be free of coercion induced by threats, promises or violence, but a positive right to make a free choice as to whether to remain silent or speak to the authorities. ${ }^{80}$

In that case, the suspect was induced to speak to someone he thought was another prisoner, who was in fact someone in authority and therefore his right to silence was infringed. It can also be noted that in Sinclair ${ }^{81}$ the justices, in dissent, argued that the majority judgment appeared to be part of a broader trend of balancing individual rights against societal interests outside of section 1. The dissent in Sinclair believed that the majority's conception of the right to silence and the right to counsel "effectively recognizes a new police power of virtually unfettered access, for the purposes of endless interrogation, to custodial detainees who have chosen to remain silent". ${ }^{82}$

Most recently and importantly the police tactic characterized as the "Mr. Big" sting has reached the Court. ${ }^{83}$ This undercover RCMP interrogation technique is aimed at inducing a confession from a suspect where there is no evidence and involves enticing the individual through rewarding involvement in illegal activity and finally culminating in a meeting with the big boss whereby the individual must confess to all previous criminality. It is at this point that the confession is recorded and the suspect arrested. On August $7^{\text {th }}, 2014$ the Court ruled that confessions generated from the RCMP's "Mr. Big" investigation technique are to be presumed inadmissible at trial. The Crown is allowed however to convince the judge that the reliability of a confession outweighs its prejudicial effects. In this particular case, the Court ruled that Nelson Hart's confession to an undercover officer about drowning his twin daughters should not be admitted as there were significant social and financial inducements to confess. There was also no other evidence leading to Hart's culpability. Comparatively "the Mr. Big operation is not used in the United States, perhaps raising doubt as to it's efficiency and reliability." 84

\footnotetext{
76 Ibid at pa.47.

77 [2007] 3 SCR 405.

78 Ibid at pa. 15.

79 [1990] 2 SCR 151.

80 Ibid at pa.54.

81 Sinclair, supra at note 49.

82 Ibid at pa. 128.

${ }^{83}$ R. v Hart (2014) SCC 52. This particular technique was used in the widely publicized wrongful conviction involving the false confession of Kyle Unger. See R. v Unger (1993) 85 Man. R.(2d) 284.

84 Pieters, S. A., \& Frank, R.E. (2016). Police Interrogations and The Psychology of False Confessions. CanLII Docs 388. http://www.canlii.org/t/2bvw at p.17 with reference to R. v. Osmar, 2007 ONCA 50 at pa. 54.
} 


\subsection{Jailhouse Informant Testimony}

Jailhouse informers are notorious as a class of self-serving and unreliable witnesses. Widespread recognition of their inherent unreliability has grown in the aftermath of public inquiries into wrongful convictions where jailhouse informers figured prominently. ${ }^{85}$

In the inquiry into the wrongful conviction of Thomas Sophonow ${ }^{86}$ Justice Cory recommended that jailhouse informants as a rule should not be allowed to testify. However, Justice Fred Kaufman in the inquiry into the wrongful conviction of Guy Paul Morin found otherwise. ${ }^{87}$ This was notwithstanding the abundant evidence that two jailhouse informants were clearly providing perjured testimony on numerous occasions and in the face of Kaufman finding the informants evidence as "wholly unreliable". ${ }^{88}$ Indeed, he found that "[t]heir evidence was motivated by self-interest. They were predisposed, by character and psychological make-up to lie." 89

The Court's decision in $R . v$ Brooks $^{90}$ raises serious problems for the prospect of wrongful convictions and the test for admissibility of unreliable evidence. In that case, a one and one-half year old girl was beaten to death in her crib. Only the accused and the infant's mother had access to the child on the night of the murder. There was a good deal of forensic evidence but much of it was contaminated and did not inculpate or exculpate the accused. There was no direct evidence that the accused had struck the fatal blows to the infant. The Crown led evidence from two jailhouse informants who testified that the accused, while incarcerated, had admitted that he had killed the child to stop her crying. Both informants had lengthy criminal records including crimes of dishonesty and both had histories of testifying as jailhouse informants in previous trials.

A Vetrovec ${ }^{91}$ warning may serve as a protection to a defendant when an unreliable witness testifies against them. This warning entails a judge admonishing a jury through a "clear and sharp warning" with respect to the testimony of disreputable or unsavoury witnesses. This evidence requires that:

1. the evidence of certain witnesses is identified as requiring special scrutiny;

2. the characteristics of the witness that bring his or her evidence into serious question are identified;

3. the jury is cautioned that although it is entitled to act on the unconfirmed evidence of such a witness, it is dangerous to do so; and

4. the jury is cautioned to look for other independent evidence which tends to confirm material parts of the evidence of the witness with respect to whom the warning has been given.

The trial judge in Brooks did not provide a Vetrovec warning to the jury about the danger of relying on jailhouse informant testimony. On appeal to the Court, it was held:

There was no error of law on the part of the trial judge in failing to provide a Vetrovec warning. It was within the discretion of the trial judge whether to give a warning and there was a foundation for his exercise of discretion...Trial judges must not pigeon-hole witnesses into categories and should examine all factors that might impair the worth of a witness. No Vetrovec warning is necessary if the trial judge believes the witness can be trusted even if the witness is a jailhouse informant. The facts raised preliminary doubts as to the credibility of the informants but not cogent reasons to overrule the trial judge's implicit finding that they were sufficiently trustworthy not to mandate a caution. ${ }^{92}$

As such, what is recognized as the most unreliable and potentially dishonest evidence available that contributes to wrongful convictions is not presumptively excluded in the case against an accused. Indeed:

Canadian warnings still eschew corroboration by deferring to the ability of the jury to accept an unsavory witness's

85 FPT, supra at note 55. The public inquiries referenced were The Morin Inquiry (Kaufman Commission): Guy Paul Morin (Ontario, 1998) and The Sophonow Inquiry (Cory Commission): Thomas Sophonow (Manitoba, 2001).

86 Ibid.

87 The Morin Inquiry (Kaufman Commission): Guy Paul Morin (Ontario, 1998).

https://www.attorneygeneral.jus.gov.on.ca/english/about/pubs/morin/.

88 Ibid at p.544.

89 Ibid.

90 [2000] 1 SCR 237.

91 R. v Vetrovic [1982] 1 SCR 811.

92 Ibid at pa.1-5. 
testimony in the absence of any independent confirmation..$^{93}$

\subsection{The Constitutional Obligation of Crown Disclosure}

The lack of cooperation and the withholding of evidence, particularly exculpatory evidence was historically a significant contributor to wrongful conviction cases. At times the police kept evidence from the Crown which never found its way to the defence and at other times the Crown had all relevant evidence from the police and yet it kept evidence from defence counsel. ${ }^{94}$ For those accused that are factually innocent of the crime for which they have been charged, the importance of knowing the case they face is significant simply because the Crown is in possession of and has access to greater resources. In this regard and as stated by Roach:

The Supreme Court's section 7 jurisprudence giving the accused a broad right to disclosure of relevant evidence in the possession of the Crown is arguably the most important development in our criminal justice system in the last quarter century. It has transformed the way the justice system operates and this new right has been crafted in no small part as a systemic measure that would apply across cases to lower the risk of wrongful convictions. ${ }^{95}$

The failure to disclose exculpatory evidence was shown to be an important contributing factor in the wrongful conviction of Donald Marshall. ${ }^{96}$ In this case the Crown did not disclose to defence counsel inconsistent statements made by the two eye witnesses who provided the fundamental evidence that led to Marshall's conviction nor did the Crown tell the defence that after the conviction alibi evidence came to light that would have cleared Marshall which was not disclosed for the purposes of an appeal to the Court of Appeal for Nova Scotia. ${ }^{97}$

Following closely on the release of the Report on Donald Marshall was the Court's decision in R. $v$ Stinchcombe ${ }^{98}$ where the right to disclosure was constitutionalized as a principle of fundamental justice under s.7. The Court held that all relevant and non-privileged information in the possession of the Crown should be disclosed without regard to whether the information was inculpatory or exculpatory and without regard to whether statements related to a person who might be called as a witness. In coming to this conclusion, the Court reviewed whether "societal interests" would be harmed by this expanded right. Justice Sopinka predicted that disclosure disputes could be avoided by the adoption of "uniform, comprehensive rules for disclosure" and that disclosure could increase efficiency by producing an "increase in guilty pleas, withdrawal of charges and shortening or waiving of preliminary hearings". ${ }^{99}$ For the purposes of making a full answer and defence to charges in a criminal proceeding, the Stinchcombe rule is now relied upon in every jurisdiction in Canada as a guarantor of full disclosure. More recently the Court has reemphasized that:

Unlike the decision to initiate or continue a prosecution, the decision to disclose relevant information is not discretionary. Rather disclosure is a constitutional obligation which must be properly discharged by the Crown in accordance with an accused's right to make full answer and defence, as guaranteed under ss.7 and 11(d) of the Charter. ${ }^{100}$

\subsection{Charter Remedies at Trial and the Exclusion of Evidence}

In the event that defence counsel at trial is successful in persuading the court that a breach of a client's rights has occurred, it is crucial to appreciate how any such breach will be treated by the court with respect to the admission of such tainted evidence.

93 Roach, supra at note 64, p.409 with reference to the Lamer Inquiry pertaining to the wrongful convictions of Ronald Dalton, Gregory Parsons and Randy Druken (2006) at http://www.justice.gov.nl.ca/just/lamer/LamerReport.pdf.

${ }^{94}$ See the Reference re Milgaard (1992) 1 SCR 866. The withholding of evidence was often a consequence of police activity characterized as tunnel vision and noble cause corruption.

95 Roach, K. (2006). The Protection of Innocence Under Section 7 of the Charter. (2006). Supreme Court Law Review: Osgoode's Annual Constitutional Cases Conference, 34 (2), 249 - 303 at p.265.

96 The Marshall Inquiry (Hickman Commission) Donald Marshall Jr. (Nova Scotia, 1989). https://novascotia.ca/...inquiry/_.../Royal\%20Commission\%20on\%20the\%20Donald\%.

97 Ibid at p.4. Chief Justice Hickman on the Reference went so far as to criticize the trial judge's role in the wrongful conviction. It was found that the trial court took it upon itself to "convict" Marshall of a robbery with which he was never charged and that the court did not deal with the significant failure of the Crown to disclose evidence to defence counsel. Reference at p.23.

98 [1991] 3 SCR 326.

99 Ibid at pa.13.

100 Per Moldaver, J. in Henry v. British Columbia (Attorney General) [2015] 2 SCR 214 at pa.59. This action was for damages resulting from a breach of the Charter. The plaintiff was successful. 
The procedural remedies for breaches of sections 7-14 of the Charter are found in s.24 (1) ${ }^{101}$ and (2). ${ }^{102}$

The broad language of s.24 (1) ${ }^{103}$ authorizes courts to impose creative remedies for Charter violations, so long as these are "appropriate and just in the circumstances'. Indeed, the Court held that "it is improper for courts to reduce this discretion by casting it in a straitjacket of judicially prescribed conditions." 104 The principal limit on judges' remedial powers under s.24(1) is that they may not encroach on the legitimate powers of the legislative and executive branches of government, except where this is justified by the language of the Charter right which was violated. A court ordering a Charter remedy must strive to respect the relationships with and separation of functions among the legislature, the executive and the judiciary; there is no "bright line" separating these functions in all cases. A remedy may be appropriate and just notwithstanding that it might touch on functions that are principally assigned to the executive. The essential point is that the courts must not, in making orders under s. 24(1), depart unduly or unnecessarily from their role of adjudicating disputes and granting remedies that address the matter of those disputes. ${ }^{105}$

The most dramatic remedy that a judge can order under s.24 (1) within the context of the trial when there is a Charter breach is a stay of proceedings. It is dramatic because when a stay is ordered, the prosecution comes to an end and the accused is no longer facing the allegation of criminality. This particular remedy is most often preserved when an accused's rights to a speedy trial have been breached pursuant to s.11 (b). ${ }^{106}$ This is not endemic to wrongful convictions and will not be explored further. Section 24(2) on the other hand, is used extensively in the face of evidence obtained as a result of a breach: the remedy in those cases is the exclusion of the evidence so obtained.

Prior to the Charter, the law in Canada had always been that evidence that was relevant to the determination of guilt or innocence would be admissible regardless of the manner by which it was derived. Any notions of doubt concerning the possibility of adhering to a rule of exclusion in Canada were laid to rest in $R . v$. Wray ${ }^{107}$ in which the Court clearly established an inclusionary rule with regard to the admissibility of illegally obtained evidence.

As a consequence, prior to the Charter, even if the rights of the individual were violated in obtaining evidence, it would nevertheless have been admitted if it was considered relevant. In this respect, the potential remedy in s.24 (2) to facilitate exclusion marked a shift from the crime control to the due process model. It is clear why an exclusionary remedy would be accepted by the due process approach as a proper remedy to ensure the integrity of the process. It is equally clear, however, why such a remedy could not be condoned by the crime control model, as it sacrifices both efficiency as well as the repression of criminal conduct. This is conveyed by Packer:

The police are bound to make mistakes, and it is of course desirable that these mistakes be minimized. Here, as elsewhere, the way to deal with mistakes is to afford a remedy for actual damages suffered by people whose privacy has been improperly invaded and to correct, by discipline and education, the future conduct of the officers who make the mistakes. It is unwise and unnecessary to provide the allegedly injured party with a windfall in the form of freedom from criminal conviction when his guilt is demonstrable... In any event, there is no reason why evidence should not be used in the criminal process without regard to the manner in which it has been obtained ${ }^{108}$

From a due process point of view however, Packer sets out that that the exclusion of evidence is appropriate in that:

... departmental discipline is an ineffective deterrent. The only practical way to control illegal searches is to take the

101 24(1) Anyone whose rights or freedoms, as guaranteed by this Charter, have been infringed or denied may apply to a court of competent jurisdiction to obtain such remedy as the court considers appropriate and just in the circumstances.

102 24(2) Where, in proceedings under subsection (1), a court concludes that evidence was obtained in a manner that infringed or denied any rights or freedoms guaranteed by this Charter, the evidence shall be excluded if it is established that, having regard to all the circumstances, the admission of it would bring the administration of justice into disrepute.

103 Justice McIntyre in Mills v the Queen [1986] 1 SCR 863 stated “...it is difficult to imagine language which could give the court a wider and less fettered discretion." This decision was one of the earliest decisions of the Court on the appropriate remedy for a breach of s.11(b) where the right to a speedy trial was infringed.

104 Vancouver (City) $v$ Ward [2010] 2 SCR 28 at pa.18.

105 See: Doucet-Boudreau v. Nova Scotia (Minister of Education), [2003] 3 SCR 3.

106 Now see the Court's decision in R. v. Jordan [2016] 1 SCR 631 wherein a new framework for a presumptive ceiling was established beyond which delay from the charge to the actual or anticipated end of trial is presumed to be unreasonable, absent exceptional circumstances to justify said delay. The presumptive ceiling is 30 months for cases tried in the provincial superior court and 18 months for cases tried in the provincial court.

107 [1971] SCR 272.

108 Packer, supra at note 3, p.199. 
profit out of them. This means that any evidence illegally obtained cannot be permitted as evidence ${ }^{109}$

The Court's first major s. 24(2) decision, $R$. v. Collins ${ }^{110}$, released in 1987, established the now-familiar three-part analytical framework for determining the admissibility of unconstitutionally obtained evidence. The "Collins test" directed judges to consider:

(1) the effect of admitting the evidence on the fairness of the trial;

(2) the seriousness of the violation; and

(3) the effect of exclusion on the repute of the administration of justice.

This was followed by R. $v$ Stillman ${ }^{111}$ where the majority of the Court held that unconstitutionally obtained evidence obtained and otherwise undiscoverable "conscriptive" 112 evidence "must be excluded". 113 What was referred to as the Collins/Stillman test for exclusion was dispensed with categorically when R. v Grant ${ }^{114}$ was decided in 2009. In this case, three police officers were on patrol in a school district that was known for its criminal activity. Grant, a young black man, was walking down a sidewalk and was seen fidgeting with his coat and pants in a way that aroused one officer's suspicions. The officer stopped Grant and began questioning him which included a request for his name and address. Grant continued to act suspiciously. At one point he appeared nervous and adjusted his jacket, which prompted the officer to ask him to keep his hands in front of him. After observing this exchange, two officers joined in and took up positions behind the first officer clearly obstructing any opportunity for Grant to move forward. The first officer then asked Grant whether he had anything he should not have, to which Grant answered that he had "a small bag of weed" and a firearm. Grant was then arrested and searched and the marijuana and a loaded revolver were seized. Defence counsel, at trial, argued that Grant's Charter rights relative to detention under sections 9 and 10 were breached and as a result, the revolver should be excluded from evidence by virtue of s.24(2). The Court affirmed that the detention was arbitrary and contrary to the Charter, but did not exclude the revolver.

The Grant majority's new test for exclusion eliminates the "trial fairness" branch of the Collins test and repackages the remaining two sets of Collins factors into a new three-prong test. Significantly, the majority in Grant characterized the s. 24(2) exclusionary remedy as solely directed at "societal" concerns, stating:

Section 24(2) is not aimed at punishing the police or providing compensation to the accused, but rather at systemic concerns. The s. 24(2) focus is on the broad impact of admission of the evidence on the long-term repute of the justice system. ${ }^{15}$

The Chief Justice and Justice Charron declared that "'trial fairness' in the Collins/Stillman sense is no longer a determinative criterion for the s. 24(2) inquiry". ${ }^{116}$ Given that the ruling in Grant has substantially diminished the prominence of trial fairness, the connection between good faith police conduct and the exclusion of unconstitutionally obtained evidence now warrants critical scrutiny. Since incorporating the assessment of investigatory behaviour into the s. 24(2) calculus, the Court has effectively established a presumption of good faith with respect to all police conduct. This raises a presumption that is only realistically rebuttable by specific evidence of flagrant and intentional bad faith on the part of subject officers. When such evidence is unavailable, police investigators will be considered to have acted in good faith, a fact that militates strongly against the exclusion of unconstitutionally obtained evidence. The majority in Grant made it abundantly clear that there is no quasi-automatic exclusionary rule for any form of evidence, including non-discoverable conscriptive evidence. However, a statement by the Court in R.v. Mann ${ }^{117}$ still has authority in that "good faith is but one factor in the analysis and must be

\footnotetext{
109 Ibid at p.200.

110 [1987] 1 SCR 265.

111 [1997] 1 SCR 607.

112 Conscriptive evidence is evidence that comes from the accused as a result of a Charter violation by the police. This type of evidence usually arises when the police question someone without telling them they have the right to speak to a lawyer, or question them when they have been illegally detained.

113 Stillman, supra at note 111, pa.98.

114 [2009] 2 SCR 353.

115 Ibid at pa.70.

116 Ibid at pa.121.

117 [2004] 3 SCR 59.
} 
considered alongside other factors." 118

Nonetheless, evidence obtained by the police in the exercise of the systemically recognized evidence gathering tactics characterized as tunnel vision and noble cause corruption will more than likely not be excluded. ${ }^{119}$

\section{Conclusion}

As Barbara Hudson states "justice is very much under threat in the risk society." 120 The interest balancing that is described by Packer's normative criminal justice models of crime control and due process have evolved in Canada into considerations by the Court as to how the rights of an accused are to be offset by public safety concerns best embodied in "societal interests". As has been seen, this balancing act plays a role in the admission of evidence that can feed into the operation of the systemic causes of wrongful convictions.

Such considerations under the Oakes test ${ }^{121}$ will determine that evidence prescribed by law will be admitted notwithstanding a breach of the Charter. It is an open question whether "societal interests" will override s. 7 rights without benefit of the Oakes test and as the majority made clear in Sinclair, ${ }^{122}$ society's needs to investigate and solve crimes provides the police with unfettered access to accused persons under interrogation. The Court has defined the confessions rule and the right to silence finely having regard to these imperatives.

With the enactment of the Charter, defence counsel confidently expected that an infringement of a client's rights in the course of a police investigation would result in the exclusion of tainted evidence. Exclusion could be avoided however if a court was convinced that the breach was justified to advance "societal interests". Further, to make exclusion even more difficult, the Court in Grant $^{123}$ changed the well-known formula under s.24 (2) to effectively remove trial fairness as a determining factor when considering exclusion. The Court has now established a presumption of good faith for virtually all police investigatory activity leaving counsel with the opportunity to exclude constitutionally challenged evidence only where its discovery can be painted with flagrant and intentional bad faith on the part of the police.

\section{References}

Beck, U. (1992). Risk Society: Toward a New Modernity. London, SAGE Publishers.

Blackstone, W. (1765-1769). Commentaries on the Laws of England.

Campbell, L. (2006). Decline of Due Process in the Irish Justice System: Beyond the Culture of Control. Hibernian Law Journal, 6, $125-158$.

Cohen, S. (1985). Visions of Social Control: Crime, Punishment and Classification. Cambridge, Polity Press.

Emmerson, B., Ashworth, A., \& Macdonald, A. (eds.). (2007). Human Rights and Criminal Justice (2nd). London, Sweet \& Maxwell.

Ewald, F. Insurance and Risk (Chp.10)., \& Castel, R., From Dangerousness to Risk (Chp.14) in Burchell, G., Gordon, C., \& Miller, P. (eds.) (1991). The Foucault Effect: Studies in Governmentality. Chicago, The Univ. of Chicago Press.

Federal Provincial Territorial Heads of Prosecutions Committee. (2011). The Path to Justice: Preventing Wrongful Convictions.

Feeley, M., \& Simon, J. (1992). The new penology: Notes on the emerging strategy of corrections and its implications. Criminology, 30, 449-474. https://doi.org/10.1111/j.1745-9125.1992.tb01112.x

Feeley, M., \& Simon, J. (1994). Actuarial justice: The emerging new criminal law. In D. Nelken (eds.) The Futures of Criminology London: Sage Publications.

\footnotetext{
118 Ibid, Iacobucci, J. at pa.55. to make a charge stick.

120 Hudson, supra at note 18 .

121 Oakes supra at note 42.

122 Sinclair, supra at note 49.

123 Grant, supra at note 114.
}

119 Tunnel vision is a narrow focus taken by the police and Crown counsel in investigating and prosecuting a crime when a particular investigative or prosecutorial theory is accepted to the exclusion of others so as to unreasonably colour the evaluation of evidence received and the response to said evidence. Tunnel vision leads to a reduction in critically assessing evidence which might lead away from the truth. Noble cause corruption is police misconduct committed in the name of perceived justice. Noble cause corruption includes planting or fabricating evidence, lying or the fabrication and manipulation of facts through testimony in court, and generally abusing police authority 
Foucault, M.. "Governmentality" in in Burchell, G., Gordon, C., \& Miller, P. (eds.). (1991). The Foucault Effect: Studies in Governmentality. Chicago, The Univ. of Chicago Press.

Garland, D (2001). The Culture of Control: Crime and Social Order in Contemporary Society. Chicago, The University of Chicago Press. https://doi.org/10.7208/chicago/9780226190174.001.0001

Hudson, B. (2003). Justice in the Risk Society: Challenging and Re-Affirming Justice in Late Modernity. London, Sage Publications.

Hudson, B. Punishment, Rights and Difference: Defending Justice in The Risk Society. Chapter 8, at p.144 in Stenson. K., \& Sullivan. R. (eds.). (2012). Risk, Crime and Prudentialism Revisited. Crime, Risk and Justice: The Politics of Crime Control in Liberal Democracies. London, Willan.

Innocence Project, Affiliated with the Benjamin N. Cardozo School of Law at Yeshiva University, New York.

MacFarlane, B. (2006). Convicting the Innocent: A Triple Failure of Justice. Man. L. J. 31, $403-488$.

The Marshall Inquiry (Hickman Commission) Donald Marshall Jr. (Nova Scotia, 1989). https://novascotia.ca/...inquiry/_.../Royal\%20Commission\%20on\%20the\%20Donald\%.

Mathews, J. (2018). Rights in the Balance. Review of Constitutional Studies, 23 (1), 225 - 233.

The Morin Inquiry (Kaufman Commission): Guy Paul Morin (Ontario, 1998). https://www.attorneygeneral.jus.gov.on.ca/english/about/pubs/morin/

O'Malley, Pat. (2008). Governmentality and Risk: Social Theories of Risk and Uncertainty, Zinn, J. (ed.). Oxford, Sydney Law School Research Paper. https://doi.org/10.1002/9781444301489.ch3

O’Malley, P. (2010). Crime and Risk. London, Sage Publishing.

Orris, G. (2017). Section 10(b) of the Canadian Charter of Rights and Freedoms: Legal Advice. The Advocate, 355.

Packer, H. (1968). The Limits of the Criminal Sanction. Stanford, Stanford Univ. Press.

Pieters, S. A., \& Frank, R.E. (2016). Police Interrogations and The Psychology of False Confessions. CanLII Docs 388. http://www.canlii.org/t/2bvw.

Reno, J. Remarks at the American 2000 National Symposium of Indigent Defence, as noted in Worden, A.P.S., Lucas, A., \& Blaize Brown. E. (2010). Patchwork of Policies: Justice, Due Process, and Public Defense across American States. Alb. L. Rev. 74: 1423 - 1464.

Roach, K. (2006). The Protection of Innocence Under Section 7 of the Charter. (2006). Supreme Court Law Review: Osgoode's Annual Constitutional Cases Conference, 34 (2), 249 - 303.

Roach, K. (2007). Unreliable Evidence and Wrongful Convictions: The Case for Excluding Tainted Identification Evidence and Jailhouse and Coerced Confessions. Crim. L. Q., $210-236$.

Roach, K. (2010). Wrongful Convictions: Adversarial and Inquisitorial Themes. N.C. Int'l. \& Com. Reg., 35 (2). 387 - 446.

Roach, K. (2012). Wrongful Convictions in Canada. U. of Cinn. L.R. 80 (4), 1465 - 1526.

Sherrin, C. (2005). False Confessions and Admissions in Canadian Law. Queens L. J. 30 (2), $601-659$.

The Sophonow Inquiry (Cory Commission): Thomas Sophonow. (Manitoba, 2001). https://www.innocencecanada.com/exonerations/thomas-sophonow/

Thompson, S. (2008). Beyond a Reasonable Doubt - Reconsidering Uncorroborated Eyewitness Identification Testimony. U.C. Davis L. Rev. 41(4), 1487 - 1546.

\section{Copyrights}

Copyright for this article is retained by the author(s), with first publication rights granted to the journal.

This is an open-access article distributed under the terms and conditions of the Creative Commons Attribution License which permits unrestricted use, distribution, and reproduction in any medium, provided the original work is properly cited. 